\section{Don't cross the (invisible) line}

\author{
Phil Wiffen
}

A recent undercover investigator for The Telegraph newspaper ${ }^{1}$ in the UK uncovered some worrying practices. Allegedly some senior pharmacists set up their own advisory boards and sold their services to pharmaceutical companies. The meetings were held in various locations such as Dubai with charges of up to UK $£ 15000$ being charged to the pharma companies in addition to lavish expenses related to flights, top hotels and meals. It is alleged that the board meetings resulted in increased use of the drugs under discussion. One of the pharmacists involved subsequently resigned and another has been suspended. There is said to be an inquiry at the highest level by the NHS England fraud department. ${ }^{2} 3$

Pharmacists have expertise in a wide range of issues relating to procurement. Commonly they are required to manage budgets or organise medicine purchases of potentially millions of Euros. In addition many understand how decisions are made at the highest level in hospitals and often oversee formulary committees and related medicine management groups. Such privileges carry a high degree of responsibility.

This type of knowledge is valuable and there are those willing to pay for inside experience and expertise. A pharmaceutical company who can have its product added onto a formulary can potentially make huge sums and so tempting offers can be made to pharmacists for help and advice in achieving that aim.

In addition, some pharmacists join with other colleagues to work on

Correspondence to Professor Phil Wiffen, Pain Research Unit, Churchill Hospital, Oxford OX3 7LE, UK; phil.wiffen@ndcn.ox.ac.uk industry-related focus groups or advisory boards. Such boards may seek to identify the best ways to introduce new drugs but also will frequently explore how to influence local formularies.

Senior hospital pharmacists need to be cautious. Advisory boards can be legitimate but if personal payment is received then it would be wise for this to be conducted in the pharmacists' own time. All such involvement must be declared to line managers and appropriately recorded. Advisory board members should not be part of a decision-making process where there is an actual or potential conflict of interest.

\section{THE RESPONSIBILITY OF THE INDUSTRY}

The pharmaceutical industry is absolutely vital to the health of our populations and we all benefit from drug discoveries and developments made, particularly, over the last five decades. Most of the time the industry gets it right but occasionally financial interests lead to bad decisions that bring the whole industry into disrepute. Recent examples include paroxetine and coxib analgesics where important adverse event data was made public.

The pharmaceutical industry professional bodies in most countries have codes of practice. These set out what is permitted for issues such as advertising, promotion of unlicensed products and guidance on entertaining. Fines are levied for those who contravene the code and these may run into thousands of Euros.

The key principle is stated as: No gift, pecuniary advantage or benefit may be supplied, offered or promised to members of the health professions or to other relevant decision makers in connection with the promotion of medicines or as an inducement to prescribe, supply, administer, recommend, buy or sell any medicine. ${ }^{45}$

This has not failed to stop the industry investing millions of Euros into the promotion of its products, and most of the funds (in the USA estimated at US\$24 million in 2012) going towards promotions and detailing aimed at clinicians

At the end of the day, it is about professionalism-something that pharmacists are generally well versed in. The challenge is to ensure that we maintain that professionalism when time is pressured. It is important to avoid any actions that would cause embarrassment if made public. What may seem like an attractive shortterm gain can lead to long-term loss such as a career as a pharmacist. If in doubt, seek advice.

Competing interests None declared.

Provenance and peer review Commissioned; internally peer reviewed.

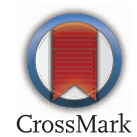

To cite Wiffen P. Eur J Hosp Pharm 2015;22:313.

Eur J Hosp Pharm 2015;22:313.

doi:10.1136/ejhpharm-2015-000820

\section{REFERENCES}

1 http://www.telegraph.co.uk/news/nhs/11755884/ Lavish-trips-laid-on-by-drugs-firms-to-sway-NHS-staff. html (accessed October 2015).

2 http://www.bbc.co.uk/news/uk-england-33654000 (accessed October2015).

3 http://www.pharmaceutical-journal.com/news-andanalysis/news/nhs-england-launches-investigation-intodrug-company-payments/20069065.article (accessed October 2015).

4 ABPI Code of Practice. http://www.pmcpa.org.uk/ thecode/Pages/default.aspx (accessed October 2015).

5 The European Federation of Pharmaceutical Industries and Associations. http://www.efpia.eu/ (accessed October 2015). 